\title{
Abnormalities at Chromosome Region 3p12- 14 Characterize Clear Cell Renal Carcinoma
}

\author{
Peter R. Carroll, V. V. S. Murty, Victor Reuter, \\ Suresh Jhanwar, William R. Fair, Willet F. Whitmore, \\ and R. S. K. Chaganti
}

ABSTRACT: In an effort to determine whether or not any characteristic chromosomal abnormalities exist in renal cancer, cytogenetic findings were correlated with tumor histology in nine cases of renal adenocarcinoma. Metaphase preparations adequate for analysis were obtained from cultures harvested between day 3 and day 21. Model chromosome number was diploid in three cases, hypodiploid in three, and hyperdiploid in the remaining three. One clear cell adenocarcinoma failed to reveal any chromosomal abnormality. Two tumors, a tubular/papillary carcinoma and an acinar/papillary carcinima, showed the clonal abnormalities $\operatorname{del}(1)(\mathrm{p} 2 \mathrm{l}),+2,+7,+8,+12,+13,+16,+17,-21$ and $\mathrm{t}(2 ; 10)(q 14-21 ; \mathrm{q} 26),+7 q,+11 q,-18$, respectively. Interestingly, five of six clear cell tumors studied had clonal abnormalities affecting the short arm of chromosome \#3 in the 3p12-21 region, and in the remaining case, of 15 karyotyped metaphases suitable for interpretation, one showed a deletion in $3 p$. These data indicate that clear cell carcinoma of the kidney may be associated with a nonrandom chromosomal abnormality involving the 3p12-14 region.

\section{INTRODUCTION}

Almost all human cancers, when studied appropriately, will show changes in chromosome structure or number $[1,2]$. These findings take on added significance when it is noted that the chromosome breakpoints identified in human tumors frequently correlate with the location of cellular oncogenes [3]. There are few cytogenetic studies of primary renal carcinomas. Cohen et al. described a family with herediatary renal carcinoma and a constitutional balanced translocation between chromosomes \#3 and \#8: $t(3 ; 8)(p 21 ; q 24)[4]$. Subsequently, high resolution G-banding analysis documented that the chromosome \#3 breakpoint occured at $3 p 14.2$, rather than 3 p21 [5]. Another familial renal carcinoma was reported with a $t(3 ; 11)(p 13-14 ; p 15)$ limited only to tumor cells [6]. Wang et al. described abnormalities of chromosomes \#3 and \#6 in fresh renal tumors and cell lines [7]. Recently, Yoshida et al. described rearrangements involving chromosome \#3 in eight of 12 nonfamilial renal

From the Urology Service, Department of Surgery and the Cancer Genetics and Cytogenetics Laboratory, Department of Pathology, Memorial Sloan-Kettering Cancer Center, New York, NY.

Dr. Carroll is a Clinical Fellow of the American Cancer Society.

Address requests for reprints to Dr. R. S. K. Chaganti, Laboratory of Cancer Genetics and Cytogenetics, Memorial Sloan-Kettering Cancer Center, 1275 York Avenue, New York, NY 10021.

Received May 19, 1986; accepted August 18, 1986. 
carcinomas [8]. Deletion of $3 p$ was noted in four cases, translocations involving chromosome \#3 in four cases, and an $\mathrm{i}(3 \mathrm{p})$ in one case. Additional clonal changes were noted in these and in two other tumors. In two additional sporadic renal carcinomas studied, clonal abnormalities were noted, but none affected the 3p13-14 region $[9,10]$. In an effort to confirm these reports and see if any additional chromosomal abnormalities might exist in these tumors, cytogenetic findings were correlated with tumor histology in nine cases of primary, nonfamilial renal adenocarcinoma.

\section{MATERIALS AND METHODS}

Primary tumor samples were obtained at the time of surgery from patients with either local or metastatic renal carcinoma. Tumor samples were transferred immediately to the laboratory, where they were minced and then disaggregated either mechanically or enzymatically. In the latter cases, tumor samples were exposed to either warm trypsin $(0.025 \%)$ or collagenase $(0.1 \%)$, hyaluronidase $(0.01 \%)$ and DNase $(0.002 \%)$ [11]. The cells were washed three times with Hank's balanced salt solution or RPMI 1640 medium. Aliquots of tumor cells were transferred to $25-\mathrm{cm}^{2}$ plastic culture flasks and incubated in RPMI 1640 medium supplemented with $15 \%$ fetal calf serum, $1 \%$ glutamine, and antibiotics (penicillin $100 \mu \mathrm{m} / \mathrm{ml}$ and streptomycin $100 \mu \mathrm{g} / \mathrm{ml}$ ) in an atmosphere of $5 \% \mathrm{CO}_{2}$. Medium was changed after $24-48$ hours and dead or nonattached cells were removed. Proliferating cultures were exposed to colcemid $[0.01$ to $0.02 \mu \mathrm{g} / \mathrm{ml}$ ) for 3-12 hours depending on the mitotic

Figure 1 Partial karyotype of five clear cell adenocarcinomas with clonal abnormalities at the 3p13-14 region. Cases 2 and 3 show del(3)(p13), whereas, case 4 shows a deletion occurring more proximally, del(3)(p12). Cases 1 and 5 show dir ins(3)(p13p21).

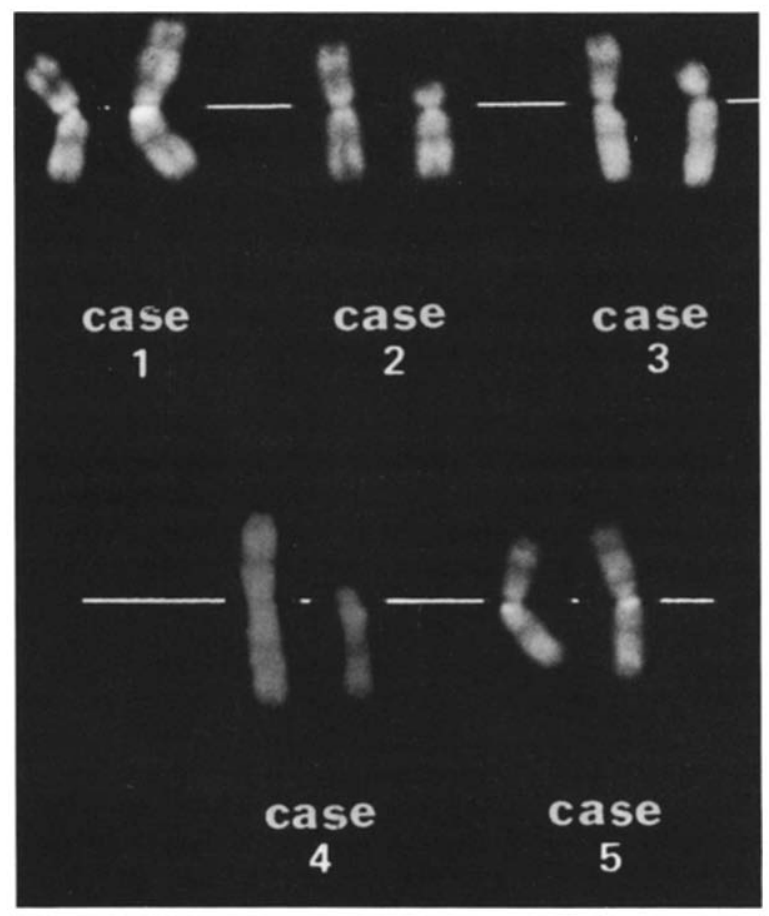


activity of the culture. The cultered cells were detached using $0.025 \%$ trypsin with EDTA. Cells were then treated with $0.075 \mathrm{M} \mathrm{KCl}$, fixed with methanol/acetic acid (3:1), and applied to standard, glass microscope slides. Chromosomes were analyzed using either Q- or G-banding, as previously described [12]. Metaphase chromosomes were analyzed and modal number was recorded [13]. The clinical stage along with the particular histologic type of tumor was recorded in each case.

\section{RESULTS}

Metaphase preparations adequate for interpretation were obtained from nine renal adenocarcinomas after 3-21 days of culture (Table 1). The tumors were removed from four women and five men, aged 38-73 years. All tumor stages were represented, but histology varied. Modal chromosome number was 46 in three cases, hypodiploid in three, and hyperdiploid in the remaining three cases. Several interesting cytogenetic abnormalities were noted. The most common clonal abnormality involved the short arm of chromosome \#3. Five clear cell carcinomas showed clonal abnormalities in this region (Fig. 1). These abnormalities seemed to be localized to the 3p12-21 region and included del(3)(p13) in two cases, dir ins(3)(p13p21) in two cases, and del( 3$)(p 12)$ in one case. The origin of the inserted segments could not be determined with certainty. An additional clear cell carcinoma had 15 metaphases adequate for interpretation and in one del(3)(p13) was noted. One renal adenocarcinoma (case 7) showed no chromosomal abnormalities. Case 8 had a tubular/ papillary carcinoma that contained $\operatorname{del}(1)(\mathrm{p} 21 \rightarrow \mathrm{pter})$ plus either addition or loss of

Table 1 Clinical and cytogegetic features of renal cell carcinoma

\begin{tabular}{|c|c|c|c|c|c|c|}
\hline \multirow{2}{*}{$\begin{array}{l}\text { Case } \\
\text { number }\end{array}$} & \multirow[b]{2}{*}{ Sex/Age (yr) } & \multirow[b]{2}{*}{ Histology } & \multirow[b]{2}{*}{ Stage } & \multicolumn{2}{|c|}{$\begin{array}{c}\text { Chromosome } \\
\text { number }\end{array}$} & \multirow[b]{2}{*}{ Karyotype } \\
\hline & & & & Mode & Range & \\
\hline 1 & $\mathrm{M} / 64$ & Clear cell & IV & 45 & $42-78$ & $\begin{array}{l}45, X Y, \operatorname{dir} \operatorname{dup}(1)(q 12 \rightarrow \\
\text { q44),dir ins(3) } \\
(\text { p13p21), }-15\end{array}$ \\
\hline 2 & $\mathrm{~F} / 52$ & Clear cell & I & 44 & $36-83$ & $44, X,-X \operatorname{del}(3)(p 13),-9$ \\
\hline 3 & $F / 41$ & Clear cell & IV & 63 & $38-79$ & $\begin{array}{rl}63 & \mathrm{XX}+\mathrm{X}, \operatorname{del}(3)(\mathrm{p} 13) \\
& +1,+2,+4,+9,+10 \\
& +12,+13,+14,+15 \\
& +16,+19,+21,+22 \\
& +7 q+, 11 q+, \mathrm{i}(8 \mathrm{q})\end{array}$ \\
\hline 4 & $\mathrm{~F} / 73$ & Clear cell & IV & 46 & $43-89$ & $46, \mathrm{XX}, \operatorname{del}(3)(\mathrm{p} 12)$ \\
\hline 5 & $F / 54$ & Clear cell & III & 49 & $32-72$ & $\begin{array}{l}\text { 49,XX,dir ins }(3) \\
\quad(\mathrm{p} 13 \mathrm{p} 21),+2,+7 \\
\quad+16\end{array}$ \\
\hline 6 & $\mathrm{M} / 61$ & Clear cell & IV & 46 & $32-83$ & $46, X Y, \operatorname{del}(3)(p 13)^{a}$ \\
\hline 7 & $\mathrm{M} / 38$ & $\begin{array}{l}\text { Clear cell/ } \\
\text { papillary }\end{array}$ & I & 46 & $33-47$ & $46, X Y$ \\
\hline 8 & $\mathrm{M} / 68$ & Tubular/papillary & II & 52 & $29-56$ & $\begin{array}{l}52, X Y, \operatorname{del}(1)(p 21) \\
\quad+2,+7,+8,+12,+13 \\
\quad+16,+17,-21\end{array}$ \\
\hline 9 & $\mathrm{M} / 58$ & Acinar/papillary & II & 45 & $41-87$ & $\begin{array}{c}47, X Y, t(2 ; 10)(q 14- \\
21 ; q 26), 7 q+ \\
11 q+,-18\end{array}$ \\
\hline
\end{tabular}

${ }^{a}$ This abnormality was seen in only one of 15 metaphases karyotyped, therefore, we cannot establish its clonal nature. 


\section{$\operatorname{lin}(1-1)$}

1

2
3
II

4

5
6

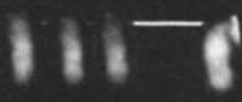

13
14
8 g

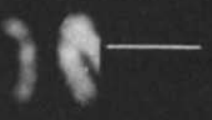

10

11

12

Figure 2 A tubular/papillary adenocarcinoma (case 8). The karyotype shown is not completely representative of the clonal karyotype, which possesses a sex chromosome constitution of XY and fails to show consistent gain of chromosome \#21.

several chromosomes (Fig. 2). Case 9 had a papillary tumor that showed $\mathrm{t}(2 ; 10)(\mathbf{q} 14$ 21;q26) and $7 q+, 11 q+$ abnormalities (Fig. 3). Additional clonal abnormalities were noted in several of the tumors.

\section{DISCUSSION}

The consistency of chromosome \#3 rearrangements in cancers of the kidney suggested in previous reports is confirmed in the present study, where six of nine tumors displayed abnormalities at region 3p. These were demonstrated to be clonal in five cases, whereas, in the sixth case only a single cell with a $3 p$ abnormality was encountered. Four of the five tumors with clonal abnormalities at chromosome region 3p12-14 possessed few additional cytogenetic changes. This strongly suggests that rearrangment at this site may play an early and perhaps critical role in tumor induction or progression. We also found that \#3 abnormalities were confined to tumors with a clear cell histology. It is not clear from several previous reports if abnormalities of chromosome \#3 occurred in any other histologic subtype. In the 


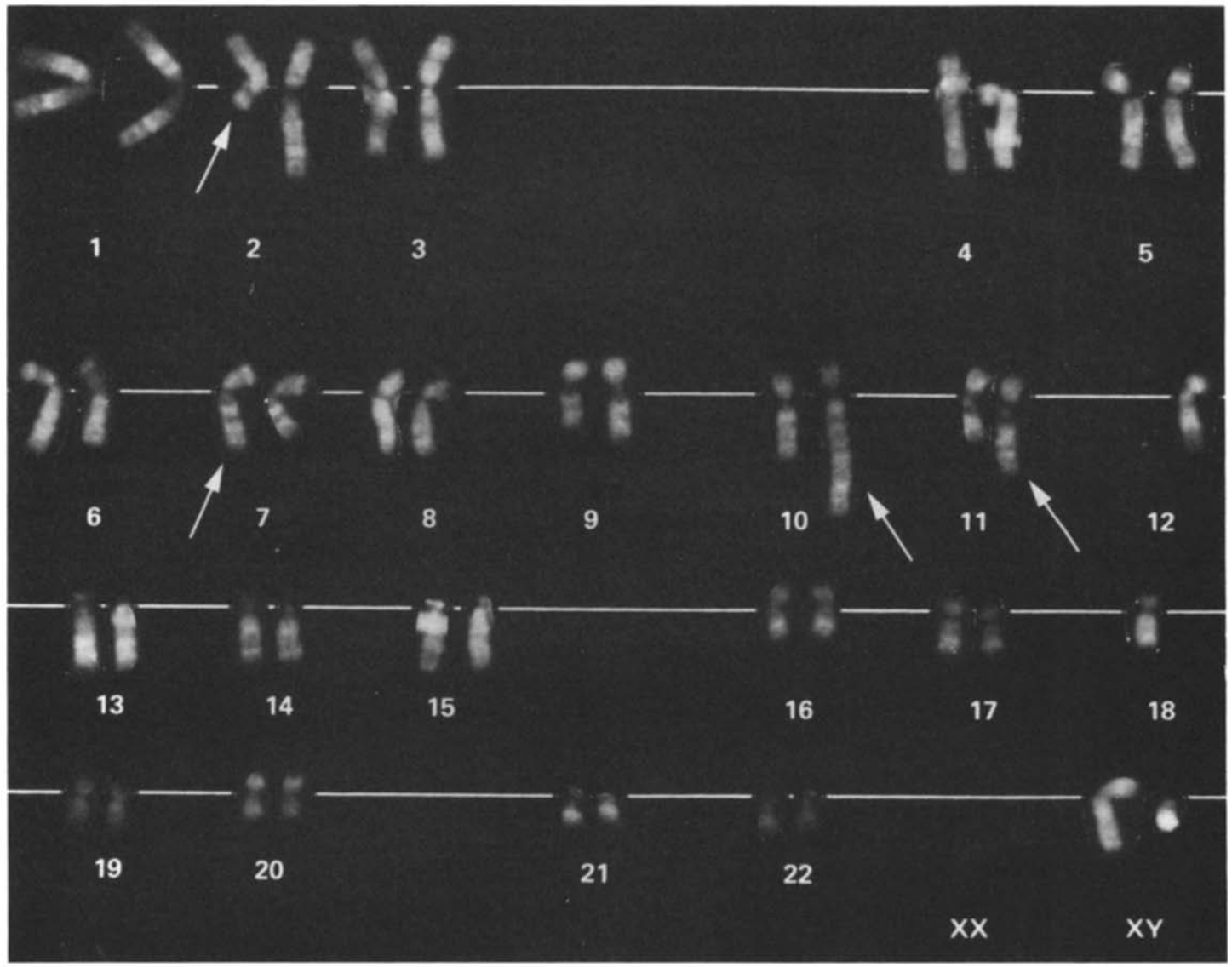

Figure 3 An acinar/papillary adenocarcinoma (case 9) showing $t(2 ; 10)(q 14-21 ; q 26)$, $7 \mathrm{q}+, 11 \mathrm{q}+$.

present study, the rarer papillary adenocarcinomas did not display abnormalities in this region. One clear cell adenocarcinoma failed to show any chromosome abnormalities. The metaphases examined in this case may have been derived from surrounding normal kidney cells that proliferated in culture. It may also be that a submicroscopic abnormality was present, but undetectable by the standard banding techniques used.

Several human tumors including small cell lung carcinomas, salivary gland tumors, rhabdomyosarcomas, and ovarian carcinomas manifest chromosomal abnormalities at the 3p13-14 region. This suggests that this chromosomal region may contain a gene or genes whose deletion or deregulation is important in the induction or growth of these tumors [14-17]. The nature of such a gene remains to be determined. The c-raf oncogene has been mapped more distally along chromosome region $3 p$ and expression of this gene has not been studied in renal cancers [18]. Drabkin et al. recently described translocation of c-myc to the 3p14.2 breakpoint in a case of hereditary renal cell carcinoma associated with a $t(3 ; 8)(p 14.2 ; q 24.13)$ chromosomal translocation [19]. Only one tumor in the present report (case 3) showed detectable abnormalities of chromosome \#8 and this was $\mathrm{i}(8 \mathrm{q})$. A possible c-ras related gene has been localized to the 3p12-14 region in human germ line chromosomes [20]. No mutations of c-Ki-ras oncogene were reported in a study of 
ten human renal carcinomas using restriction fragment length polymorphisms for this gene [21]. Trent et al. studied several rhabdomyosarcomas with abnormalities at region 3p13-14 and were unable to find a $\mathrm{H}$-ras related sequence in this region. In addition, they also failed to detect structural alterations or amplification of the c-Ha-ras or N-ras genes [16].

A certain degree of concordance exists between fragile sites, oncogene locations, and chromosomal breakpoints found in a variety of solid and hemopoeitic neoplasms [22]. The 3p13-14 region has been reported to be a common fragile site [23]. Interestingly, Pathak and Goodacre have described a patient with a renal carcinoma that showed a $t(3 ; 8)$. The patient did not have a constitutional translocation, but his peripheral lymphocytes showed an increased expression of the fragile site at the 3p13-14 region after treatment with FUdR and caffeine, suggesting that somatic expression of a constitutional fragile site may lead to a clonal karyotypic abnormality in the tumor [24].

Balanced chromosomal translocations involving oncogene locations are common in hemopoetic neoplasms [25]. These rearrangements are thought to lead to oncogene activation and neoplastic transformation. Alternatively, solid tumors including the renal adenocarcinomas in the present study rarely show balanced translocations and such tumors are more frequently characterized by either nonreciprocal chromosome translocations or deletions [26]. Certain solid tumors may be a product of gene loss with activation of a tumor-promoting recessive allele. Retinoblastomas and Wilms' tumors, both, are thought to arise in such a fashion [27-29]. Whether or not such a gene exists at the 3p12-14 site and is responsible for the induction of renal carcinoma and other solid tumors with similar chromosomal abnormalities remains to be determined.

Our data confirm that renal adenocarcinoma is associated with a nonrandom chromosomal abnormality at the 3p12-14 region. In the present study, this abnormality was confined to tumors with a clear cell histology. Because several solid tumors possess similar abnormalities, continued study of this region may provide important insights into the genetic mechanisms of cancer induction or maintenance.

\section{REFERENCES}

1. Sandberg AA (1980): The Chromosomes in Human Cancer and Leukemia. Elsevier-North Holland, NY.

2. Rowley JD (1980): Chromosome abnormalities in cancer. Cancer Genet Cytogenet 2:171198.

3. Rowley JD (1983): Human oncogene locations and chromosome aberrations. Nature 301:290-291.

4. Cohen AJ, Li FP Berg S, Marchetto DJ, Tsai S, Jacobs SC, Brown RS (1979): Hereditary renal cell carcinoma associated with a chromosomal translocation. N Engl J Med 301:592595.

5. Wang N, Perkins KL (1984): Involvement of band 3p14 in $t(3,8)$ hereditary renal carcinoma. Cancer Genet Cytogenet 11:479-481.

6. Pathak S, Strong LC, Ferrell RE, Trinidade A (1982): Familial renal carcinoma with a 3;11 chromsome translocation limited to tumor cells. Science 217:939-940.

7. Wang N, Soldat L, Fan S, Figenshaw S, Clayman R, Fraley E (1984): The consistent involvement of chromosome 3 and 6 aberrations in renal cell carcinoma. Am J Hum Genet 35:73A.

8. Yoshida MA, Ohyashiki K, Ochi H, Gibas Z, Prout GR, Pontes EJ, Huben R, Sandberg AA (1986): Rearrangement of chromosome 3 in renal cancer. Cancer Genet Cytogenet 19:351354. 
9. Ferti-Passantonopoulou A, Panani A, Raptis S (1984): G-banded karyotype of a primary renal cell carcinoma. Cancer Genet Cytogenet 11:227-232.

10. Hecht F, Berger CS, Sandberg AA (1985): Nonreciprocal chromosome translocation $t(5,14)$ in cancers of the kidney: Adenocarcinoma of the renal parenchyma and transitional cell carcinoma of the kidney pelvis. Cancer Genet Cytogenet 14:197-203.

11. Rong GH, Grimm EA, Sindelar WF (1985): An enzymatic method for consistent production of mondispersed viable cell suspensions from solid tumors. J Surg Oncol 28:131-133.

12. Caspersson T, Farber S, Wagh U, Zech L (1968): Chemical differentiation along metaphase chromosomes. Exp Cell Res 49:219-222.

13. ISCN (1978): An International System for Human Cytogenetic Nomenclature (1978). Birth Defects: Original Article Series, Vol. XIV, No. 8 (The National Foundation, New York, 1978); also in Cytogenet Cell Genet 21:309-404 (1978).

14. Whang-Peng J, Kao-Shan LS, Lee EC, Bunn PA, Garney DN, Gazdar AF, Minna JD (1982): Specific chromosome defect associated with human small cell lung cancer: Deletion 3p(14-23). Science 215:181-182.

15. Mark J, Dahlenfors R, Edhedahl C, Stenman G (1980): The mixed salivary gland tumorA normally benign human neoplasm frequently showing specific chromosomal abnormalities. Cancer Genet Cytogenet 2:231-241.

16. Trent J, Casper J, Meltzer P, Thompson F, Fogh J (1985): Nonrandom chromosomal alterations in rhabdomyosarcoma. Cancer Genet Cytogenet 16:189-197.

17. Trent J, Salmon SE (1981): Karyotypic analysis of human ovarian carcinoma cells cloned in short term agar culture. Cancer Genet Cytogenet 3:279-291.

18. Bonner T, Rapp U, Nash WG, O Brien SJ (1984): Two human homologs to a new retroviral oncogene raf-1 and raf-2 are assigned to chromosomes 3 and 4 , respectively. Human Gene Mapping, Los Angeles Conference, Seventh International Workshop on Human Gene Mapping. Cytogenet Cell Genet 37:424.

19. Drabkin HA, Bradley C, Hart I, Bleskan J, Li FP, Patterson D (1986): Translocation of cmyc in the herediatary renal cell carcinoma associated with a $t(3 ; 8)(p 14.2 ; q 24.13)$ chromosomal translocation. Proc Natl Acad Sci 82:6980-6984.

20. Jhanwar SC, Neel BG, Hayward, WS; Chaganti, RSK (1983): Localization of c-ras oncogene family in human germ line chromosomes. Proc Natl Acad Sci USA 80:4794-4797.

21. Duesberg PH (1985): Activated proto-oncogenes: Sufficient or necessary for cancer? Science 228:669-677.

22. LeBeau MM, Rowley JD (1984): Heritable fragile sites in cancer. Nature 308:607-608.

23. de la Chapelle A, Berger R (1984): Report of the committee on chromosome rearrangments in neoplasia and on fragile sites. Cytogenet Cell Genet 37:274-311.

24. Pathak S, Goodacre A (1986): Specific chromosome anomalies and predisposition to human breast, renal cell and colorectal carcinoma. Cancer Genet Cytogenet 19:29-36.

25. Rowley JD (1984): Biological implications of consistent chromosome rearrangements in leukemia and lymphoma. Cancer Res 44:3159-3168.

26. Atkin NB (1986): Lack of reciprocal translocations in carcinomas. Cancer Genet Cytogenet 21:275-277.

27. Murphee AL, Benedict WF (1984): Retinoblastoma: Clues to human oncogenesis. Science 223:1028-1033.

28. Knudson AG (1985): Hereditary cancer, oncogenes and antioncogenes. Cancer Res 45:1437-1443.

29. Koufos A, Hansen MF, Lampkin B, Workman M, Copeland N, Jenkins ND, Cavenee W (1984): Loss of allele at loci in human chromosome 11 during genesis of Wilms' tumor. Nature 309:170-173. 